research support from: Abbvie, Celgene, Centocor, Merck, Novartis, Consultant for: Abbvie, BMS, Boehringer-Ingelheim, Celgene, Eli Lilly, Hospira, Janssen, Merck, Novartis, Novo, Orion, Pfizer, Regeneron, Roche, and UCB, Speakers bureau: Abbvie, BMS, Boehringer-Ingelheim, Celgene, Eli Lilly, Hospira, Janssen, Merck, Novartis, Novo, Orion, Pfizer, Regeneron, Roche, and UCB

DOI: 10.1136/annrheumdis-2019-eular.4960

\section{FRI0379 LONG-TERM EVALUATION OF SECUKINUMAB 150 MG IN ANKYLOSING SPONDYLITIS: 5-YEAR END-OF-STUDY EFFICACY AND SAFETY RESULTS FROM A PHASE 3 TRIAL}

Helena Marzo-Ortega ${ }^{1}$, Joachim Sieper ${ }^{2}$, Alan Kivitz ${ }^{3}$, Ricardo Blanco ${ }^{4}$ Martin Cohen ${ }^{5}$, Karel Pavelka ${ }^{6}$, Eumorphia Maria Delicha ${ }^{7}$, Anna Stefanska ${ }^{8}$, Hanno Richards ${ }^{7}$, Susanne Rohrer. ${ }^{7}$ NIHR Leeds Biomedical Research Centre, Leeds Teaching Hospitals NHS Trust, University of Leeds, Leeds, United Kingdom; ${ }^{2}$ University Clinic Benjamin Franklin, Berlin, Germany, ${ }^{3}$ Altoona Center for Clinical Research, Duncansville, United States of America; ${ }^{4}$ Hospital Universitario Marqués de Valdecilla, Santander, Spain; ${ }^{5}$ Mc Gill University, Montreal, Canada; ${ }^{6}$ Institute of Rheumatology and Department of Rheumatology, 1st Faculty of Medicine, Charles University in Prague, Prague, Czech Republic; ${ }^{7}$ Novartis Pharma AG, Basel,

Switzerland, ${ }^{8}$ Novartis Ireland Limited, Dublin, Ireland

Background: Evaluation of long-term efficacy and safety for treatments for ankylosing spondylitis (AS) is important. Secukinumab, a fully human monoclonal antibody that directly inhibits interleukin-17A, has shown significant and sustained improvement in the signs and symptoms of AS through 3 years in the MEASURE 2 study (NCT01649375). ${ }^{1}$

Objectives: We report the 5-year end-of-study results of subcutaneous (s. c.) secukinumab $150 \mathrm{mg}$ in the MEASURE 2 study.

Methods: AS patients (pts; $N=219$ ) were randomised to receive s.c. secukinumab $150 \mathrm{mg}, 75 \mathrm{mg}$ or placebo at baseline, Weeks (Wks) 1, 2 and 3 and every 4 wks from Wk 4 . At Wk 16, placebo-treated pts were re-randomised to receive secukinumab $150 / 75 \mathrm{mg}$. Efficacy results are reported for pts initially randomised to secukinumab $150 \mathrm{mg}$ and those who switched from placebo to secukinumab $150 \mathrm{mg}$ at Wk $16(\mathrm{~N}=$ 106). An optional dose escalation from secukinumab $75 \mathrm{mg}$ to $150 \mathrm{mg}$ was initiated beginning Wk 140. Outcome measures at Wk 260 included ASAS20/40, BASDAI50, BASMI, BASFI, SF-36 PCS and ASAS partial remission. Analyses stratified by anti-TNF status (anti-TNF-naïve and antiTNF inadequate response [IR]) were performed. Safety analysis included all pts who received $\geq 1$ dose of secukinumab. Results are reported as observed.

Results: The retention rate to Wk 260 was $77 \%$ (82/106) for secukinumab $150 \mathrm{mg}$. Sustained efficacy was observed with secukinumab $150 \mathrm{mg}$ across all endpoints through 5 years (Table). Improvements were maintained regardless of prior exposure to anti-TNF therapy with greater responses in anti-TNF-naïve pts. A total of 49 pts on secukinumab 75 $\mathrm{mg}(46.7 \%)$ escalated dose to $150 \mathrm{mg}$ after Wk 140; efficacy responses improved in pts whose dose was escalated. Over the entire study period, the mean exposure $( \pm S D)$ to secukinumab was $1459.1 \pm 597.8$ days. Exposure-adjusted incidence rates (per 100 pt-years) with any secukinumab dose for selected adverse events were: Candida infections (1.0), Crohn's disease (0.5), major adverse cardiovascular events (0.7), uveitis $(0.5)$, and malignant/unspecified tumours (0.5).

Conclusion: Secukinumab $150 \mathrm{mg}$ provided sustained improvement in the signs, symptoms, and physical function in pts with AS through 5 years of treatment. The safety profile of secukinumab remained consistent with previous reports. ${ }^{1-3}$

\section{REFERENCES:}

[1] Marzo-Ortega, et al. RMD Open. 2017;3:e000592; 2. Marzo-Ortega, et al. Ann Rheum Dis. 2016;75:812-3; 3. Baraliakos X, et al. Clin Exp Rheumatol 2017.

Disclosure of Interests: Helena Marzo-Ortega Grant/research support from: Janssen, Novartis and Pfizer, Consultant for: AbbVie, Celgene, Janssen, Eli-Lilly, Novartis and UCB, Speakers bureau: AbbVie, Celgene, Janssen, Eli-Lilly, Novartis and UCB, Joachim Sieper Consultant for: Abbvie, Böhringer Ingelheim, Janssen, Lilly, Merck, Mylan, Novartis, Pfizer, UCB., Speakers bureau: Abbvie, Böhringer Ingelheim, Janssen, Lilly, Merck, Mylan, Novartis, Pfizer, UCB., Alan Kivitz Shareholder of: Novartis, Consultant for: Abbvie, Janssen, Pfizer, UCB, Genzyme, Sanofi, Regeneron, Boehringer Ingelheim, Sun Pharma Advanced Research, Flexion., Paid instructor for: Celgene, Horizon, Merck, Novartis, Pfizer, Genzyme, Sanofi, Regeneron, Speakers bureau: Celgene, Horizon, Merck and Genetech,
Flexion, Ricardo Blanco Grant/research support from: Abbvie, MSD and Roche, Consultant for: Abbvie, Pfizer, Roche, Bristol-Myers, Janssen and MSD, Speakers bureau: Abbvie, Pfizer, Roche, Bristol-Myers, Janssen and MSD, Martin Cohen Consultant for: AbbVie, Amgen, Celgene, Lilly, Novartis, Pfizer, Sandoz, Sanofi and UCB, Speakers bureau: AbbVie, Amgen, Celgene, Janssen, Merck, Novartis and Pfizer, Karel Pavelka: None declared, Eumorphia Maria Delicha Employee of: Novartis, Anna Stefanska Shareholder of: Novartis, Employee of: Novartis, Hanno Richards Shareholder of: Novartis Pharma AG, Employee of: Novartis Pharma AG, Susanne Rohrer Shareholder of: Novartis, Employee of: Novartis

DOI: 10.1136/annrheumdis-2019-eular.5531

Table. Efficacy Endpoints with Secukinumab $150 \mathrm{mg}$ at Week 260 (5 year)

\begin{tabular}{lccc}
\hline Variable & \multicolumn{3}{c}{ Secukinumab 150 $\mathbf{~ m g}^{\mathbf{1}}$} \\
\cline { 2 - 4 } & $\begin{array}{l}\text { Total } \\
\mathbf{N}=\mathbf{1 0 6}\end{array}$ & $\begin{array}{c}\text { Anti-TNF-naïve } \\
\mathbf{N}=\mathbf{6 6}\end{array}$ & $\begin{array}{c}\text { Anti-TNF-IR } \\
\mathbf{N}=\mathbf{4 0}\end{array}$ \\
\hline ASAS20 $^{2}$ & $69.9(83)$ & $73.7(57)$ & $61.5(26)$ \\
ASAS40 $^{2}$ & $54.2(83)$ & $63.2(57)$ & $34.6(26)$ \\
ASAS-Partial Remission $^{2}$ & $25.3(83)$ & $28.1(57)$ & $19.2(26)$ \\
BASDAI50 $^{2}$ & $53.0(83)$ & $56.1(57)$ & $46.2(26)$ \\
BASMI $^{3}$ & $-0.7 \pm 1.2(80)$ & - & - \\
BASFI $^{3}$ & $-2.8 \pm 2.6(83)$ & - & - \\
${\text { SF-36 } \text { PCS }^{3}}^{\text {Payyy}}$ & $8.0 \pm 8.5(79)$ & $8.5 \pm 8.9(56)$ & $6.8 \pm 7.4(23)$ \\
\hline
\end{tabular}

Data are reported as observed; ${ }^{1}$ Includes placebo switchers; ${ }^{2} \%$ responders (n); ${ }^{3}$ mean

change from baseline $\pm S D(n)$; IR, inadequate response; $N$, total number of randomised patients; $n$, number of evaluable patients; TNF, tumour necrosis factor

\section{\begin{tabular}{|l|l|l|l}
\hline FRI0380 SECUKINUMAB PROVIDES SUSTAINED IMPROVEMENT &
\end{tabular} OF ENTHESITIS IN PATIENTS WITH ANKYLOSING SPONDYLITIS: POOLED ANALYSIS OF FOUR PIVOTAL PHASE 3 STUDIES}

Georg Schett ${ }^{1}$, Xenofon Baraliakos ${ }^{2}$, Filip van den Bosch ${ }^{3}$, Atul Deodhar ${ }^{4}$, Lianne S. Gensler ${ }^{5}$, Mikkel Ǿstergaard $^{6}$, Shital Agawane ${ }^{7}$, Ayan Das Gupta ${ }^{7}$, Shephard Mpofu ${ }^{8}$, Todd Fox ${ }^{9}$, Adam Winseck ${ }^{9}$, Abhijit Shete ${ }^{8}$, Brian Porter ${ }^{9}$. ${ }^{1}$ Friedrich Alexander University Erlangen-Nuremberg, Department of Internal Medicine, Erlangen, Germany, ${ }^{2}$ Rheumazentrum Ruhrgebiet, and Ruhr University Bochum, Herne, Germany; ${ }^{3}$ Ghent University Hospital, Ghent, Belgium; ${ }^{4}$ Oregon Health and Science University, Oregon, United States of America; ${ }^{5}$ University of California, San Francisco, United States of America; ${ }^{6}$ Copenhagen Center for Arthritis Research (COPECARE), University of Copenhagen, Copenhagen, Denmark; ${ }^{7}$ Novartis Healthcare Pvt Ltd, Hyderabad, India: ${ }^{8}$ Novartis Pharma AG, Basel, Switzerland; ${ }^{9}$ Novartis Pharmaceuticals Corporation, East Hanover, United States of America

Background: Enthesitis can be a debilitating extra-articular spondyloarthritis (SpA) manifestation and cause of considerable pain and reduced quality of life/physical function. ${ }^{1,2}$

Objectives: To evaluate the effect of secukinumab (SEC) on axial and peripheral enthesitis in ankylosing spondylitis (AS) patients (pts) with baseline enthesitis (BLE) across all Maastricht AS EnthesiS (MASES) sites $(\mathrm{N}=13)$, axial MASES sites $[\mathrm{N}=11 ; 13$ MASES minus Achilles tendons (AT); AxS], peripheral sites ( $N=6$; $A T$ + lateral condyles of humerus/femur; PS) and the AT ( $N=2$; AT) at Weeks (W) 16 and 52.

Methods: This post hoc analysis pooled data across 4 SEC studies in AS (MEASURE 1-4) from pts originally randomised to SEC $150 \mathrm{mg}$ (approved dose in AS), 300mg (MEASURE 3 only), or placebo (PBO) with BLE (MASES >0). Study designs have been reported previously. Evaluations include mean change from $\mathrm{BL}$ in MASES score, complete resolution $(C R$; MASES $=0$ ) and improvement from $B L$ in MASES score of $\geq 5$ counts. Mixed-effect model repeat measurement (MMRM) analysis was done on change from BL in MASES score and non-responder imputation for resolution of enthesitis at W16; data are reported as observed at W52.

Results: A total of $355(70.4 \%), 58(76.3 \%)$, and $280(72 \%)$ pts had BLE in $150 \mathrm{mg}, 300 \mathrm{mg}$ and $\mathrm{PBO}$ groups, respectively. BL characteristics were generally comparable across groups. At W16, mean change from BL for overall MASES and at AxS was greater for SEC 150mg $(-2.4$ and -2.3$)$ and $300 \mathrm{mg}(-2.9$ and -2.9$)$ vs PBO $(-1.9$ and $-1.8 ; P<0.05$ and $<0.01)$. At $W 16$, pts treated with SEC $150 \mathrm{mg}(40.8 \%$ and $42.7 \%)$ and $300 \mathrm{mg}(36.2 \%$ and $42.1 \%)$ vs PBO $(28.9 \%$ and $30.1 \%)$ achieved CR of enthesitis based on overall MASES and at AxS. SEC150mg and $300 \mathrm{mg}$ were also consistently associated with higher mean change in MASES and $\mathrm{CR}$ of enthesitis at PS and individually at AT vs PBO. A higher proportion of pts treated with SEC $150 / 300 \mathrm{mg}$ vs PBO achieved a higher threshold of improvement ( $\geq 5$ counts) in overall MASES at W16. Further improvements were observed for all endpoints at W52 (Table). 
Conclusion: Secukinumab was associated with higher mean change in MASES and complete resolution of enthesitis compared to placebo at Week 16, which further improved through Week 52.

\section{REFERENCES:}

11] Braun J, et al. Nat Clin Pract Rheumatol. 2006;2:536-45; 2. Schett G, et al. Nat Rev Rheumatol. 2017;13:731-741.

Table. Summary of results

\begin{tabular}{|c|c|c|c|c|c|}
\hline & \multicolumn{2}{|c|}{$\begin{array}{c}\text { SEC } 150 \mathrm{mg} \\
\quad \mathrm{N}=355\end{array}$} & \multicolumn{2}{|c|}{$\begin{array}{c}\text { SEC } 300 \mathrm{mg} \\
\mathrm{N}=58\end{array}$} & \multirow{2}{*}{$\begin{array}{c}\text { PBO } \\
\mathrm{N}=\mathbf{2 8 0}\end{array}$} \\
\hline & $\overline{\text { W16 }}$ & W52 $^{\circ}$ & W16 & W52 $^{\circ}$ & \\
\hline \multicolumn{6}{|c|}{ LS mean change from BL in MASES score ${ }^{*}$} \\
\hline Overall MASES ${ }^{a}$ & $-2.4^{\ddagger}$ & -3.5 & $-2.9^{\S}$ & -3.9 & -1.9 \\
\hline $\mathrm{AxS}^{\mathrm{b}}$ & $-2.3^{\ddagger}$ & -3.2 & $-2.9^{\S}$ & -3.6 & -1.8 \\
\hline PS $^{c}$ & -1.3 & -1.9 & -1.6 & -2.1 & -1.2 \\
\hline$A T^{d}$ & -1.0 & -1.2 & -1.0 & -1.3 & -0.8 \\
\hline \multicolumn{6}{|c|}{ Complete resolution of enthesitis (MASES=0) } \\
\hline Overall MASES $^{a}$ & $40.8^{\S}$ & 56.4 & 36.2 & 52.9 & 28.9 \\
\hline$A x S^{b}$ & $42.7^{\S}$ & 58.6 & 42.1 & 60.0 & 30.1 \\
\hline PS $^{c}$ & 46.3 & 65.5 & 52.5 & 69.7 & 38.3 \\
\hline$A T^{d}$ & 57.0 & 78.4 & 55.0 & 77.8 & 48.0 \\
\hline \multicolumn{6}{|c|}{ Improvement from BL in MASES score ( $\geq 5$ counts) $)^{\#}, \%$} \\
\hline Overall MASES $^{a}$ & 23.7 & 34.1 & 27.6 & 43.1 & 16.1 \\
\hline$A x S^{b}$ & 20.1 & 28.0 & 22.8 & 32.0 & 15.4 \\
\hline \multicolumn{6}{|c|}{ 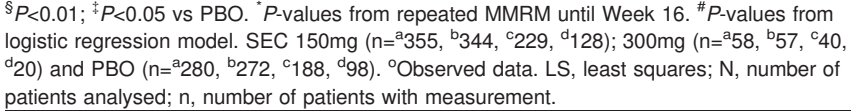 } \\
\hline
\end{tabular}

Disclosure of Interests: Georg Schett: None declared, Xenofon Baraliakos Grant/research support from: AbbVie, Boehringer Ingelheim, Bristol-Myers Squibb, Celgene, Centocor, Chugai, Janssen, MSD, Novartis, Pfizer Inc Roche and UCB, Grant/research support from: AbbVie, Pfizer, Merck Sharp \& Dohme, UCB Pharma, Novartis, Consultant for: AbbVie, BristolMyers Squibb, Boehringer Ingelheim, Celgene, Chugai, Janssen Biologics, Novartis, Pfizer, UCB Pharma, Galapagos, Speakers bureau: AbbVie, Chugai, Janssen, Novartis, Pfizer, UCB Pharma, Filip van den Bosch Consultant for: AbbVie, BMS, Galapagos, Janssen, Lilly, Merck, Novartis, Pfizer and UCB, Speakers bureau: AbbVie, BMS, Janssen, Lilly, Merck, Novartis, Pfizer and UCB., Atul Deodhar Grant/research support from: AbbVie, Amgen, Eli Lilly, GSK, Janssen, Novartis, Pfizer, and UCB, Consultant for: AbbVie, Amgen, BMS, Eli Lilly, Janssen, Novartis, Pfizer, and UCB, Lianne S. Gensler Grant/research support from: Abbvie, Amgen, UCB Pharma

, Consultant for: Novartis, Lilly, Janssen, Mikkel Ǿstergaard Grant/research support from: Abbvie, Celgene, Centocor, Merck, Novartis, Consultant for: Abbvie, BMS, Boehringer-Ingelheim, Celgene, Eli Lilly, Hospira, Janssen, Merck, Novartis, Novo, Orion, Pfizer, Regeneron, Roche, and UCB, Speakers bureau: Abbvie, BMS, Boehringer-Ingelheim, Celgene, Eli Lilly, Hospira, Janssen, Merck, Novartis, Novo, Orion, Pfizer, Regeneron, Roche, and UCB, Shital Agawane Employee of: Novartis, Ayan Das Gupta Employee of: Novartis, Shephard Mpofu Employee of: Novartis, Todd Fox Employee of: Novartis, Adam Winseck Employee of: Novartis, Abhijit Shete Shareholder of: Novartis Pharma AG, Employee of: Novartis Pharma AG, Brian Porter Shareholder of: Novartis, Employee of: Novartis DOI: 10.1136/annrheumdis-2019-eular.695

\section{FRI0381 TROUGH SERUM DRUG LEVELS AND DISEASE ACTIVITY IN AXIAL SPONDYLOARTHRITIS PATIENTS ON LONG-TERM TREATMENT WITH TNF-A INHIBITORS}

Liseth de Wolff $^{1}$, Suzanne Arends ${ }^{1}$, Freke Wink ${ }^{2}$, Elisabeth Brouwer ${ }^{1}$,

Anneke Spoorenberg'. ' University Medical Center Groningen, University of Groningen, Rheumatology and Clinical Immunology, Groningen, Netherlands;

${ }^{2}$ Medical Centre Leeuwarden, Rheumatology, Leeuwarden, Netherlands

Background: In approximately $50 \%$ of patients with axial spondyloarthritis (ax-SpA) treated with TNF- $\alpha$ inhibitors, treatment loses efficacy after a period of time. ${ }^{1}$ Previous research has shown that high disease activity is associated with low serum drug levels after 6 months of treatment with TNF- $\alpha$ inhibitors. ${ }^{2}$ There is limited literature regarding this subject in axial SpA patients on long-term treatment with TNF- $\alpha$ inhibitors.

Objectives: To investigate the association between trough serum drug level of TNF- $\alpha$ inhibitors and disease activity in axial SpA patients.

Methods: All consecutive ax-SpA patients of the Groningen Leeuwarden Axial SpA (GLAS) cohort, fulfilling the ASAS classification criteria, treated with TNF- $\alpha$ inhibitors and visiting the out-patient clinic in Groningen between the $1^{\text {st }}$ of June 2015 until the $31^{\text {st }}$ of May 2016 were approached to have a trough serum drug level measurement within two months from the out-patient visit. Serum trough levels were stratified in a 'therapeutic' and 'below-therapeutic' range according to the reference values of Sanquin $^{3}$. Disease activity was assessed with the ASDAS, BASDAI and CRP.

Results: $67(60 \%)$ of the 112 approached patients were eligible for analy ses. Thirty-one (46\%) were male, mean age was $45 \pm 12$ years, 48 patients $(72 \%)$ were HLA-B27 positive, mean symptom duration was 20 \pm 12 years and median duration of TNF- $\alpha$ inhibitor treatment was 49 months (IQR 14-64). 34 patients were on adalimumab (51\%), followed by 21 on etanercept $(31 \%)$ and the remaining 12 patients $(18 \%)$ were on infliximab, certolizumab or golimumab. 32 of the 67 patients $(48 \%)$ had a 'therapeutic' serum trough drug level and 35 (52\%) were 'below-therapeu tic', with no significant difference in patient characteristics between these 2 groups, including disease activity (ASDAS $2.2 \pm 1.0$ vs. $2.3 \pm 0.8$; BASDAI $3.9 \pm 2.4$ vs. $4.1 \pm 2.1$; CRP 4.5, IQR 2.0-6.6 vs. 3.0, IQR 2.0-6.0). No significant correlations for ASDAS, BASDAI and CRP with adalimumab or etanercept drug level were found (adalimumab $r=-0.164, p=0.36 ; r=-0.191$, $\mathrm{p}=0.29 ; \quad \mathrm{r}=-0.041, \mathrm{p}=0.83$ resp.; etanercept $\mathrm{r}=-0.185, \mathrm{p}=0.42 ; \quad \mathrm{r}=-0.113$, $\mathrm{p}=0.63 ; \mathrm{r}=-0.216, \mathrm{p}=0.36$ resp.).

Stratified by gender, only women on adalimumab showed a weak significant negative correlation between serum level and ASDAS and BASDAI $(r=-0.444, \quad p<0.05 ; \quad r=-0.497, p<0.05$ resp.) but not for CRP ( $r=0.038$ $\mathrm{p}=0.87$ ). Compared to men, women had a significantly higher ASDAS and CRP. BASDAI was not significantly different (data not shown) Patient characteristics between patients with and without serum trough level measurements did not differ significantly.

Conclusion: In daily clinical practice random serum trough levels in ax $\mathrm{SpA}$ patients are relatively low according to reference values of Sanquin. Furthermore, only for women on adalimumab a weak correlation was found between trough serum drug level and ASDAS and BASDAI but not for CRP.

\section{REFERENCES:}

[1] Arends S., Brouwer E., Efde M. et al. Long-term drug survival and clinical effectiveness of etanercept treatment in patients with ankylosing spondylitis in daily clinical practice. Clin Exp Rheumatol 2017;35:61-68.

[2] Kneepkens E.L., Wei J.C.C., Nurmohamed M.T, et al. Immunogenicity, adalimumab levels and clinical response in ankylosing spondylitis patients during 24 weeks of follow-up. Ann Rheum Dis 2015;74:396-401.

[3] Sanquin Amsterdam. Diagnostische testen. Available via: www.sanquin. org/nl/producten-en-diensten/diagnostiek/diagnostische-testen/index. Consulted on April 28th 2018.

Disclosure of Interests: Liseth de Wolff: None declared, Suzanne Arends Grant/research support from: Grant/research support from Pfizer, Freke Wink Consultant for: Abbvie, Janssen, Elisabeth Brouwer Speakers bureau: Dr. Brouwer as an employee of the UMCG received speaker fees and consulting fees from Roche which were paid to the UMCG, Anneke Spoorenberg Grant/research support from: Received unrestricted grants from Pfizer, Novartis and Abbvie pharmaceuticals. They had no influence in design and conduct of the study., Consultant for: Abbvie, Pfizer, MSD,

UCB, and Novartis

DOI: 10.1136/annrheumdis-2019-eular.7200

\section{FRI0382 TEN-YEAR RETENTION RATES OF FIRST-LINE BIOLOGICAL AGENT IN AXIAL SPONDYLARTHRITIS IN DAILY PRACTICE: A ROMANIAN MULTICENTRE EXPERIENCE}

ANCUTA CODRINA $^{1,2}$, Cristina Pomirleanu ${ }^{1,2}$, Raluca Paiu $^{2}$,

Georgiana Strugariu ${ }^{2}$, Luiza Petrariu ${ }^{2}$, Eugen Ancuta ${ }^{3}$, Codruta Bran ${ }^{4}$ Rodica Chirieac ${ }^{5}$, Claudia Mihailov ${ }^{6} .{ }^{1}$ Grigore T Popa University of Medicine and Pharmacy, lasi, Romania; ${ }^{2}$ Clinical Rehabilitation Hospital, lasi, Romania; ${ }^{3}$ Elena Doamna Clinical Hospital, lasi, Romania; ${ }^{4}$ Sf loan cel Nou Clinical Emergency Hospital, Suceava, Romania; 5 SANOCARE Medical and Research Center, lasi, Romania; ${ }^{6}$ Faculty of Medicine, "Ovidius" University Constanta, Constanta, Romania

Background: Although the efficacy and long-term persistence of TNF inhibitors (TNF-i) are widely recognized in axial spondyloarthritis (axSpA), up to about one third of patients experience failure (loss of therapeutic response or toxicity) with the first biological agent requiring switching to another drug. 